The reasons of America's support of Ukraine during the "Ukrainian crisis" are generalized in terms of ensuring security, fulfillment of international commitments, realization of leadership, and protection of values. The U.S. should support Ukraine because of 1) Russia's gross violation of international norms that ruins post-war order in Europe and threatens European security; 2) the U.S.' obligations to Ukraine according to 1994 Budapest Memorandum; 3) America's status as a global leader that oblige it to protect and strengthen a rules-based international order, including the rights of small and medium nations in it; 4) its political traditions of promotion democratic and liberal values, embodied in the Ukrainian "Revolution of Dignity".

So called "Ukrainian" crisis is actually the Russia's one as it caused by Kremlin's revisionist policy. It reveals essential changes in the $21^{\text {st }}$ century world. The U.S. support of Ukraine means a defense of fundamental values and norms that shape contemporary liberal global architecture. The results of the crisis will determine the rules in world politics, fundamental features of the international order, and the U.S. role in it.

Key words: Russia's aggression against Ukraine, the U.S. policy towards Ukraine.

\title{
УКД 94(477):341.222(73)
}

http://doi.org/10.17721/2521-1706.2016.02.77-84

Наталія Ковальчук, доктор філософських наук, професор, Київський університет імені Бориса Грінченка

\section{ФЕНОМЕН ДЕМОКРАТІЇ В КОНТЕКСТІ КОРДОННОЇ ЦИВІЛІЗАЦІї УКРАЇНИ ТА США}

Анотація. Метою даної статті є репрезентація аналогових процесів формування демократичних традицій в історії США та Украйни в контексті кордонного статусу цฺих країн. Людина пограниччя, піонер $і$ ковбой, стала в багатьох аспектах репрезентативним американцем і засновником американської демократії. Українською людиною пограниччя був козак, який у XVI-XVII століттях став репрезентативним типом свого народу. Підгрунтям демократії в Україні були козаџькі спільноти, а у США -англійські громади. Подальший розвиток демократії потребував великих міст як бази державотворення. Важливу роль у розвитку украӥнської та американської демократії відігравали міста. Великі зміни в демократичному розвитку міст пов'язані з прийняттям і упровадженням Магдебурзького права. Принципи американської демократії були започатковані в містах на східному узбережжі США. Американські міста виступали як великі асамблеї, де, як і в Україні, населення користувалося правом місиевої самоуправи, мало своє право, суд, приватну свободу. Україна здобула свою свободу і незалежність проти королівської влади Польщі в ході української національно-визвольної боротьби, а США в ході американської революиії виступали за свободу і незалежність проти королівської влади Англії.

Ключові слова: демократія, вільна індивідуальність, історичні паралелі, прикордонний статус Украӥни та США.

Проблема демократії своїм корінням сягає початку цивілізаційного процесу всесвітньої історії. Як відомо цей процес почався з виникнення держави. Саме їі поява створила новий цивілізаційний аспект - аспект політичної історії, яка має різні форми правління та суспільного устрою. Серед цих форм суспільного устрою особливого значення набула демократія. У сучасному світі демократія трактується у напрямі врахування думок меншості, у першу чергу тих, хто орієнтується на нестандартну ситуацію. Тим самим у системі сучасної демократії на передній план висуваються принципи плюралізму, свободи, правової держави та толерантності. В 
українському суспільстві надзвичайно небезпечною є незріла демократія. Адже така демократія найлегше сполучається з охлократією, більше того, з диктатурою «митингової стихії». У цьому контексті важливо повернутися до історії розвитку демократичних настанов в українському суспільстві, які нажаль були втрачені, але можуть виступати основою для демократичного розвитку демократичного суспільства у майбутньому.

Метою даної статті $є$ репрезентація аналогових процесів формування демократичних традицій в історії США та України в контексті кордонного статусу цих країн. Для вирішення цієї мети необхідно проаналізувати історичні паралелі розвитку демократії в Україні та США в контексті формування носіїв вільної індивідуальності, функціонування громад як організаційних форм рівноправності та братства людей, демократичним устроєм великих міст, історичними особами, що виявили здатність очолювати національно-визвольний рух.

Демократія розвивається в Україні з того самого джерела, що й демократія європейських країн, тобто з варязьких структур варварської демократії. Але за наявності загального коріння розвиток демократії в Україні та Європі відбувається в різних соціо-політичних обставинах. Україна розвивалася на кордоні з кочовими племенами степовиків, i демократія починає набувати рис самооборони українського соціуму. Розвиток цивілізації в Україні набирає кордонного вигляду. У цьому сенсі найближчу аналогію обставин розвитку України становить розвиток кордонної цивілізації Південної Америки. Тут йдеться не про те, що доля України, чи іiі соціум, чи iї люди є схожими з американським суспільством або є піонерами прерій. Йдеться саме про аналогію генези кордонної цивілізації, про схожість початкових умов самооборони суспільства. Це типологічна, а не індивідуальна схожість розвитку, а отже, і його результатів.

У вивченні генези демократії в Україні та США методом порівняльноісторичного аналізу головним виступає врахування кордонного характеру цивілізацій цих країн у період їх формування. Тут йдеться про цивілізації, які знаходяться на кордоні між «розумною ойкуменою» культури і силами ворожнечого буття, що втілюють або стихію природи, або варварського соціуму.

I в Україні, і в США з самого початку їхнього існування $є$ кордон 3 дикою природою - «степ, прерії», і там і там є кордон між цивілізацією та варварством. Степ був джерелом постійних нападів кочових племен тюркського походження в Україні та індіанських тубільців у США і тому розглядається як хаос. Цьому хаосові і потрібно було протиставити «розумну ойкумену», якою виступало місто як софійне начало.

Якщо виходити 3 концепції А. Тойнбі, що будується за схемою «заклик відгук», то освоєння степу й було відповіддю української та американської цивілізацій на заклик універсуму. «Степ 3 простору кочовища перетворюється на переоране поле, річки - на зони перешкоди набігам у транспортні артерії, околиці міст і сіл - у хутори на зразок ферм чи ранчо», - зазначає відомий український філософ С. Кримський $[1$, с. 104]. Відповідно в українській та американській етнічній свідомості зростає цінність поняття кордону, межі, ліміту. Не випадково відомий американський історик Фредерік Джексон Тернер пропонував як плідний методологічний засіб для вивчення американської культури використовувати тезу прикордоння. Це також стосується і вивчення української культури. 
Демократію можливо розглядати як форму виживання соціуму. Цікаво, що такий підхід змінює розуміння самої демократії. Традиційно демократія розглядається як влада більшості. На нашу думку, ідея демократії пов'язана 3 проблемою людини, проблемою розвитку вільної особистості. I тому дослідження демократії повертає нас до проблеми вільної особистості. У специфічних умовах кордонної цивілізації в Україні та у США демократія була здатна до виживання тільки на грунті розвитку вільної особистості, зрозумілому у якнайширшому сенсі.

Людина пограниччя, піонер i ковбой, стала в багатьох аспектах репрезентативним американцем і засновником американської демократії. Звичаї та установки, що виникли в умовах пограниччя, забарвили весь американський побут, у тому числі й землі давнього поселення вздовж східного узбережжя.

Українською людиною пограниччя був козак, який у XVI-XVII століттях став репрезентативним типом свого народу. У своїй суті козацтво було організацією військової самооборони населення пограничних земель, для яких існувала загроза. Однак згодом військова організація, що спонтанно сформувалася на пограниччі, почала відігравати важливу роль у житті запілля.

3 поширенням феномену «поля» в українській та американській культурі відбувається становлення етнічної свідомості. На передній план виступає не опозиція «місто - степ» (як альтернатива порядку та хаосу, софійності та безодні), а зіставлення «місто - хутір», де останній символізує трансформацію степової стихії у ферму, тобто обжитий куток особисто відвойованої природи. Взагалі в українській та американській ментальності та в пов'язаних 3 ними національних культурах спостерігається паралелізм зображення життя природи і людини, органічний зв'язок природного і соціального. Степ тут не просто географічне чи екологічне явище, а соціальний грунт. «Прив'язаність до рідного грунту для українця, - пише 3 цього приводу С. Грица, - має особливий сенс, бо вона асоціюється з синдромом вічного страдництва за відсутності рідної хати - своєї держави. Поняття «рідний» в українській мові має неперекладаний ідіоматичний смисл» $[2$, с. 20].

Що стосується американської культури, то для американця «степ» асоціюється 3 вільними землями, які забезпечують йому економічну та політичну рівність, які $\epsilon$ початком його свободи і демократії. Отже, і в Україні, і в США рідна земля - це вже не тільки грунт, а рідний соціум, що асоціюється з національною державністю.

Підгрунтям демократії в Україні були козацькі спільноти, а у США англійські громади. Зародилась і зміцніла козаччина в Україні в умовах державнополітичного лихоліття на спустошеному татарами «Дикому полі» в безпосередньому сусідстві та боротьбі з кримськими нападниками. Козаччина постає як стихія без ясної мети і політичної програми. Але, об'єднавшись 3 громадянством, козаччина змінила свою роль оборонця степових окраїн на роль творця та будівничого української державності».

Розвиток демократії в США спирався на аналогічні в правовому сенсі функціональні спільноти - англійські громади Нової Англії (якщо мати на увазі норми звичаєвого права). На відміну від тих поселень, що були створені в США авантюристами, які шукали золота і пригод, емігранти з Англії приїхали зі своїми родинами i, як свідчить А. де Токвіль, не ставили собі за мету збагачення та поліпшення соціального стану. Вони шукали втілення певних ідеологічних доктрин [3, с. 31-32]. Ці емігранти, або, як вони себе називали, пілігрими, належали до 
англійської секти, чиї принципи дали їм ім'я пуритан. Пуритани мали не тільки релігійну доктрину, а й у багатьох пунктах були пов'язані з абсолютиськими і республіканськими теоріями.

Таким чином, американська демократія та державність були започатковані англійськими громадами Нової Англії. Так званий «Мейфлауер-компакт» став взірцем для нового суспільства на нових суспільних засад.».

Функціональні общини також, як і козацькі осередки, передбачали можливість не тільки територіальної вкоріненості, а й зміни місцеперебування, тому вони дають лише перший історичний поштовх до демократичного устрою. Подальший розвиток демократії потребував великих міст як бази державотворення.

Формування представницької влади в Україні було пов'язано з Конституцією Пилипа Орлика У шостому пункті Конституції постулюється утворення Генеральної Ради - «козацького парламенту» як законодавчого органу Української Гетьманської держави. Далі йдуть шістнадцять пунктів, які розкривають зміст прав і вільностей, параметри того ідеального ладу, який закладено в основу Конституції. Ідея демократичного устрою держави 3 генеральною військовою радою як головний параметр була цілком зрозумілою і всім верствам населення, i, зокрема, козацтву. Функціональне вирізнення козацького стану за фактичного проголошення рівності усієї людності роксоланової закладало прецедент в історії європейського суспільства в XV-XVI століттях. Про це пишуть також М. Костомаров і М. Максимович.

Формування представницької влади в Україні було пов'язано з Конституцією Пилипа Орлика, а в США - зі зрілою американською конституцією. Історія Америки після прийняття американської конституції - це історія реалізації засад, прийнятих у формотворчому періоді американської республіки. Основні принципи американської конституції такі: демократія, федералізм, принцип свободи та принцип рівності.

Згідно $з$ принципом демократії джерелом державної влади $\epsilon$ народ, який творить органи влади шляхом виборів. У час, коли формувалися основи американської державності, демократична форма правління була великою новиною. Батьки американської державності мусили вирішувати два актуальні питання. Першим було принципове питання про державну форму: чи це має бути монархія, чи республіка? Відомо, що сам Дж. Вашингтон вирішив прийняти республіканську форму держави i став першим президентом демократичної республіки на основі нової конституції.

Другою важливою проблемою була справа методу управління державою. До цього американці вперше в історії застосували метод виборів, конституційних і ратифікаційних конвенцій. Застосування федеративної ідеї до американської політичної дійсності виявилося дуже щасливою розв'язкою. 3 одного боку, це створило спільну федеративну владу, а за другого - давало змогу окремим штатам користуватися у всіх справах.

Принцип свободи людини означає, що людина-громадянин має певні невід'ємні права, які державна влада не сміє порушувати або скасовувати. Декларація незалежності називає три невід’ємні права людини: право на життя, свободу, змагання до щастя. Американська формула змагання до щастя $\epsilon$ неперевершеною, бо вона дозволяє кожній окремій людині визначити, в чому полягає іï щастя і залишити за собою право змагатися за нього. 
Ідея рівності також закореніла в американському суспільстві й належить до основних засад, на яких побудовано американський державний устрій. Рівність не означає зрівняння всіх під суспільним чи матеріальним оглядом, вона означає рівність у сенсі права, без будь-яких станових чи класових привілеїв, даючи рівні шанси для всіх.

Важливу роль у розвитку української та американської демократії відігравали міста. Великі зміни в демократичному розвитку міст пов'язані 3 прийняттям i упровадженням Магдебурзького права. Місто було позбавлено прямого втручання з боку існуючої влади. Це право проголошувало рівність усіх мешканців міста перед законом. Магдебурзьке право надавало великі пільги містам, бо залучало жителів міст до самоуправління, яке чинилося на принципах вибору адміністрації, судової влади тощо. Унаслідок запровадження Магдебурзького права змінився давній характер українських городів, вони перетворилися в «міста», а населення їх у «міщан», що користувалися правом місцевої самоуправи, мали свій суд, своє право.

Принципи американської демократії були започатковані в містах на східному узбережжі США. Американські міста виступали як великі асамблеї, де, як і в Україні, населення користувалося правом місцевої самоуправи, мало своє право, суд, приватну свободу. Демократизм i республіканізм панували в ранньополітичному житті міст узбережжя Нової Англії. А. де Токвіль, досліджуючи їхній розвиток, зазначає, «що саме муніципальні інститути міст $\epsilon$ гарантом духу свободи в США». Далі він наводить дуже цікавий приклад щодо механізму місцевої самоуправи в містах Нової Англії. У них існувала законодавча та адміністративна влада. Законодавча влада виробляє в населення міст повагу до влади і закону, який, як наголошує А. де Токвіль, ніде у світі не підтримується так абсолютно, як в Америці.

Україна здобула свою свободу і незалежність у ході національно-визвольної боротьби проти королівської влади Польщі. Україна, що входила до складу великого князівства Литовського, після Люблінської унії (1569р.) опинилася під пануванням Польщі Польські намагання знищити козацьку військову організацію призводили до напруження, що постійно зростало й нарешті 1648 р. вибухло великою революцією під проводом Богдана Хмельницького. Після перших боїв між козацькими та польськими силами населення волості (запілля) майже поголовно піднялося проти польського режиму. Тепер «покозачилося» багато людей, які зовсім не були козаками в первісному значенні пограничних войовників, але належали до селянства, міщанства чи навіть православної шляхти. Військова організація пограниччя поширювалася на простори, звільнені від польського панування, і виступила як основа нового суспільного та адміністративного ладу.

Україна здобула свою свободу i незалежність проти королівської влади Польщі в ході української національно-визвольної боротьби, а США в ході американської революції виступали за свободу і незалежність проти королівської влади Англії. Причини конфлікту між американськими колоніями Великої Британії та материком загальновідомі. У його основі лежали протести колоністів проти «оподаткування без репрезентації». Традиційно колонії мали власну самоуправу 3 правом накладати податки. Це було респектовано королем i парламентом. Закінчення Семилітньої війни (1756-1763рр.), в якій Велика Британія здобула перевагу над Францією і витіснила ii 3 північноамериканського континенту, 
обтяжило державну королівську скарбницю великими воєнними боргами. На основі раніше прийнятих «навігаційних актів» британський уряд наклав мито на товари, що були предметом колоніальної торгівлі. Суперечності між Англією та Америкою загострюються завдяки прийняттю «Штемпелового акта» (1675р.) і особливо «Акта Бостонського порту» $(1773$ р.). 3 приводу цього 1774 р. у Філадельфії відбувся перший конгрес представників колоній, на якому було прийнято спільну програму дій проти порушення колоніальних прав. Його учасники висунули вимогу скасувати нестерпні акти і просили короля в окремій петиції, щоб він перешкодив парламентові порушувати права колоній. Паралельно 3 петицією до короля Джорджа III стихійно почалася підготовка колоністів до збройного опору, який був початком Американської революції під керівництвом Дж. Вашингтона як головного командира Континентальної армії.

Розвиток демократії в Україні та в США був пов'язаний з авторитаризмом, якщо мати на увазі харизматичних вождів, таких як Б. Хмельницький та Дж. Вашінгтон. «Справжнім володарем» назвав Б. Хмельницького А. Віміні 1650 р. Б. Хмельницький мав усі потрібні якості - полководця, дипломата, видатного військового організатора, державного діяча. I все ж найбільша роль Б. Хмельницького в історії України полягає у його державницьких звитягах, творені Української Козацької держави. У всіх галузях державного будівництва - у війську, адміністрації, в судовій справі і культурно-освітній діяльності Б. Хмельницький скрізь виступає як державний діяч великого формату.

У процесі національно-визвольної боротьби і війни проти Польщі єдиною владою в Україні було Військо Запорозьке, а його гетьман Б. Хмельницький, вождь тієї революції, був - і лише він міг ним бути - головою нової Української держави.

Державотворення США також було пов'язане 3 історичною особою, яка репрезентувала волелюбні традиції народу. Американська революція висунула батька - засновника американської республіки Дж. Вашінгтона. Генрі Лі в похоронному слові сказав пам'ятні слова, які характеризують місце Дж. Вашінгтона в історії Америки: «Перший у війні, перший у мирі, перший у серцях земляків». Він належить до постатей, які змінюють хід історії. Можна сказати, що відбиток його духу позначився на історії всього людства.

Великим внеском, який Дж. Вашінгтон зробив в Американську революцію, була його толерантна настанова. Історики американської революції вказують, що він своєю толерантністю вплинув на ії характер і переміг. Вона не знала терору та інших крайнощів французької революції. Толерантна настанова сприяла успішному завершенню революції та визвольної війни.

Воєнний досвід переконав Дж. Вашінгтона, що майбутнє Америки залежить від створення сильної центральної влади. Засобом для того могло бути прийняття нової конституції, яка повинна була засвідчити перед усім світом, що саме народ може узаконити устрій, який забезпечить людині свободу, добробут i справедливість.

Т. Шевченко, роздумуючи про долю України, висловлював віру в те, що й Україна дочекається свого Вашінгтона. У поемі «Юродивий» він пише:

... коли

Ми діждемося Вашінгтона

3 новим і праведним законом?

А діждемось таки колись! 
Розвиток демократії в Україні та США був пов'язаний з тяжінням до ідеалів Просвітництва. Розвинений індивідуалізм українців обумовлений етикою «інтелектуалізму». Свій вклад у розвиток ідей вільної індивідуальності внесли в Україні академічні вольності, що розвиваються 3 діяльністю братств, ідей просвітництва взагалі. Вже у XV ст. по всій Україні виникають братські громадянські організації українського населення, що об'єднуються для захисту своїх станових інтересів, відстоювання своїх національно-культурних справ.

Демократична структура братств була пов'язана 3 демократичними традиціями і високим рівнем самоуправління. Братчики виступали вихователями моральних якостей людини, іiі честі й гідності. «Мали братчики пильнувати, щоб світські люди і духовні жили, слухаючись заповідей Христових, мали право докоряти їм негарне життя. А коли не послухається, писати до єпископа», наголошує Б. Грінченко [4, с. 11]. В українській культурі братства заснували принцип виборності духовенства світських людей і підпорядкування духовенства цим громадянам. При тому братства досягли такого становища, коли не клір управляв народом, а народ кліром.

Система виховання у США, як і в Україні, починалася 3 початкових шкіл, потім коледжів, які відкривали прямий шлях до американських університетів. Фредерік Тернер в своїй праці «Пограниччя в американській історії» наводить уривок з Конституції штату Індіани від 1816 року: «Загальна система виховання, яка охоплювала всі рівні, від міських шкіл до державних університетів, була безплатна і рівною мірою відкрита для всіх [5, с. 282]». При цьому він наголошує, що ця концепція була народжена на середньому Заході, у суспільстві американських піонерів.

В американській системі виховання велика роль належала університетам. Час вимагав освічених політиків, економістів, законодавців, науковців та інших фахівців, яких готували американські університети і які потім віддавали свій талант на олтар демократії. Тут доречно, мабуть, згадати слова, сказані лордом Байроном: «Навчання декількох - це деспотизм, навчання багатьох - це свобода. А інтелектуальна і принципова свобода - «це слава, мудрість і влада».

Велике значення в розвитку вільної особистості належить КиєвоМогилянській академії. Вона була світським навчальним закладом, до якої могли вступити люди всіх станів незалежно від віку.

Вчилися студенти Києво-Могилянської академії всяк на свій кошт і скільки хто забажає. Цікаво, що Р. Заборовський запровадив чіткіший внутрішній порядок в академії і видав інструкцію під назвою «Закони Києво-Могилянської академії». Головна мета навчання пов'язана з розвитком вільної особистості студентів КиєвоМогилянської академії, створенням атмосфери розкутості, яка б сприяла усвідомленню своєї цінності і гідності. В одному 3 двадцяти двох її пунктів особливо наголошується на користі публічних диспутів, які не тільки сприяють засвоєнню знань, а й готують майбутніх громадян. Студенти на диспутах могли критикувати лекції за попередній тиждень. Так виявлялися активніші і кмітливіші викладачі. На прохання керівників закладу у 1694 та 1701 рр. академія отримала царські грамоти 3 підтвердженням права на власний суд i незалежність від магістрату.

Отже, у розвитку демократії в Україні та у США є певні історичні паралелі, що пов'язані з їх прикордонним статусом і, відповідно, з потребою формування 
носіїв вільної індивідуальності, функціонування громад, як організаційної форми рівноправності та братства людей. Демократичним устроєм великих міст, як центрів державотворення, визвольною боротьбою з королівським абсолютизмом, яка стимулювала республіканські ідеї, історичними особами, що виявилися здатними репрезентувати імперативи волі у національному менталітеті. Ці паралелі свідчать про ті потенційні можливості, що були втрачені Україною внаслідок іiі колонізацією царизмом, але зараз стають історичним джерелом демократичного розвитку української державності в контексті сучасної цивілізації.

\title{
Література
}

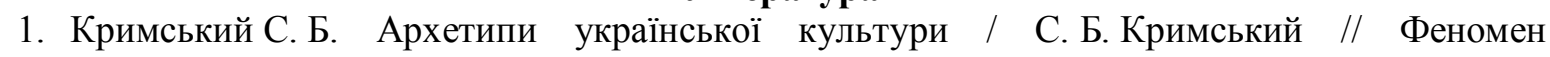
української культури: методологічні засади осмислення. - К.: Фенікс, 1996. - С. 91-112.

2. Грица С. Міграція фольклору / С. Грица // Фольклор українців поза межами України: Сб наук. статей. - AН України, Ін-т мистецтвознавства, фольклористики та етнології ім. М. Рильського, Ін-т української археології. - К., 1992. - С. 20-40.

3. De Tocqueville A. Democracy in America / Alexis de Tocqueville // Dover publications. - New York, 1996. $-375 \mathrm{p}$.

4. Грінченко Б. Братство і просвітня справа / Б. Грінченко // Черкаси, 1917. - 150 с.

5. Turner F. The frontier in American History / F. Turner // Dover publications, 1996. $-375 \mathrm{p}$.

Надійшла до редколегії 21.07.2016

Natalia Kovalchuk, Doctor of sciences in Philosophy, professor, Borys Grinchenko Kyiv University, Ukraine.

MODERN UKRAINE IN THE LIGHT OF CONCEPTS BY AMERICAN SCHOLARS

Abstract. The goal of this article is representation of analogues processes of the democratic tradition formation in the history of Ukraine and USA in context of their border status. A border man, a pioneer and a cowboy, in many aspects became represented American and a founder of the American democracy. Ukrainian border man was a Cossack, which in XVI-XVII century became representative type of their people. A ground of democracy in Ukraine was Cossack's communities, in the USA - English communities. Further development of democracy in Ukraine required big cities as a basis of state building. Big changes in democratic development of big cities were linked with introduction of the Magdeburg right. Principles of the American democracy were founded in the big cities of the Northern coast. American cities were independent assembles, where, as in Ukraine, citizens used local rights, had their courts, liberty. Ukraine got their independence against Poland during the Ukrainian national liberation struggle; USA got it during American revolution their liberty and independence against United Kingdom. The development of democracy in Ukraine and USA was linked with ideas of Enlightenment. Developed individualism of Ukrainians was influenced by ethics of «intellectualism». System of education in USA and Ukraine began since the prime school, then colleges, which opened the road to the universities.

Keywords: democracy, free individuality, historical parallels, border status of Ukraine and USA.

УДК $327(73+477)$

Оксана Осадча, кандидат політичних наук

\section{ПРІОРИТЕТИ ПАРТНЕРСТВА ЗІ СПОЛУЧЕНИМИ ШТАТАМИ АМЕРИКИ В КОНТЕКСТІ ПОСИЛЕННЯ ОБОРОНОЗДАТНОСТІ УКРАЇНИ}

\begin{abstract}
Анотація. У статті розглядаються сучасні пріоритети стратегічного партнерства України зі Сполученими Штатами Америки у сфері безпеки $і$ оборони в контексті гібридної війни, розв'язаної проти Украӥни Російською Федерацією. Аналізуються основні положення безпекової політики США, викладені в оновлених
\end{abstract}

